\title{
SOIL SEED BANKS IN LOESS GRASSLANDS AND THEIR ROLE IN GRASSLAND RECOVERY
}

\author{
*TÓTH, K. ${ }^{1}-$ HÜSE, B. ${ }^{1}$ \\ ${ }^{1}$ Universtiy of Debrecen, Department of Ecology \\ H-4032 Debrecen, Egyetem tér 1. \\ * Corresponding author \\ e-mail:kissa0306@gmail.com \\ (Received $19^{\text {th }}$ Sept 2013; accepted $18^{\text {th }}$ Dec 2013)
}

\begin{abstract}
Loess grasslands are among the most species-rich grasslands in Europe. In many regions only species-poor degraded fragments of formerly species-rich loess grasslands remained due to the agricultural intensification in the last century. To preserve and restore loess grasslands it is necessary to understand, how soil seed banks can contribute to the maintenance of diversity. We studied the vegetation and seed banks of (i) a loess grassland in a semi-natural state and (ii) a degraded loess pasture. We found that species richness was significantly lower in the degraded loess pasture $\left(10.2 \mathrm{species} / \mathrm{m}^{2}\right)$ than in the semi-natural loess grassland $\left(27.0\right.$ species $\left./ \mathrm{m}^{2}\right)$. Mean seed bank densities were quite similar in the two grassland types $\left(22,800\right.$ and $20,200 \mathrm{seeds} / \mathrm{m}^{2}$, respectively). Out of the frequent graminoids in the vegetation, only Poa angustifolia possessed considerable dense seed banks. Forb species having considerable seed banks were mainly disturbance-tolerant species (e.g. Euphorbia cyparissias, Galium verum or Hypericum perforatum). Most characteristic forb species possessed only sporadic seed banks (e.g. Filipendula vulgaris, Pimpinella saxifraga and Salvia nemorosa). Our results suggest that seed banks have only a limited role in the recovery of loess grasslands.
\end{abstract}

Keywords: grazing; grassland restoration; plant traits; propagule limitation, seed density

Introduction

Grasslands contribute with a significant part to the biodiversity of Europe harbouring a very diverse flora and fauna at multiple spatial scales (Kovács-Hostyánszky et al., 2011; 2013; Valkó et al., 2012). The extension and diversity of grasslands is in a constant decline in Europe in the past decades, thus, conservation and restoration of species-rich grasslands is an urgent task nowadays (Penksza et al. 2010, 2013; Török et al., 2011, Házi et al. 2011, 2012; Szentes et al., 2011a, 2011b; Zimmermann et al., 2011, Kiss et al., 2011). For an effective planning of conservation, it is vital to understand mechanisms sustaining grassland biodiversity (Drobnik et al., 2011, Malatinszky et al. 2013, Valkó et al., 2013).

The maintenance and recovery of species diversity in grasslands can be supported by local propagule sources preserved in the form of persistent soil seed banks (Bossuyt \& Honnay, 2008; Valkó et al., 2011). There are contrasting views on the role of soil seed banks in sustaining grassland biodiversity. Several studies stress that soil seed banks form an important source for re-colonization, especially when species dispersal is limited (Simmering et al., 2006). Persistent soil seed banks of characteristic grassland species enable fast grassland recovery after degradation or disturbances (Bossuyt \& Honnay, 2008). However, other studies found that target species often lack persistent seed banks (Kalamees \& Zobel, 1998; Bossuyt \& Honnay, 2008). Still there is a shortage of seed bank records, especially for species of high conservational value. Underrepresentation of target species in databases might also hamper the understanding of seed banks' role in grassland recovery (Csontos, 2001; Valkó et al., 2011). To design 
conservation and restoration measures in grasslands it is necessary to study soil seed banks as potential propagule sources for grassland recovery.

The species composition and density of seed banks varies considerably across grassland types and regions, thus it is necessary to have seed bank analysis and persistency records for each grassland type of high conservation value. Published seed bank type records are available for approximately $50 \%$ of the Hungarian flora (Csontos, 2001). Hungarian seed bank studies were mainly published from sandy grasslands (Halassy, 2001; Matus et al., 2003, 2005; Török et al., 2009), mountain hay-meadows (Valkó et al., 2011), native alkali (Valkó et al., 2013) and restored alkali and loess grasslands (Török et al., 2012a), rocky grasslands on dolomite (Csontos et al. 1996a), oak forests and clearcuts (Csiszár 2004; Koncz et al., 2010, 2011; Csontos 2011), and pine plantations (Csontos et al. 1996b). Seed bank studies are especially crucial in very fragile and threatened species-rich steppic grasslands, like loess grasslands (Kelemen et al., 2013; Török et al., 2012b). The seed banks of loess grasslands were formerly studied by Virágh and Gerencsér (1998), but in this study for the detected species no seed bank classification was provided.

Loess grasslands are among the most species-rich communities in Europe and harbour many threatened plant and animal species (Török et al., 2011; Török et al., $2012 \mathrm{~b}$ ). The area of historically characteristic loess grasslands become fragmented in lowland areas in Central-Europe because of the agricultural intensification in the last century (Molnár and Botta-Dukát, 1998). In many regions, only species-poor degraded fragments of formerly species rich grasslands remained surrounded by croplands and other intensively managed agricultural lands (Török et al., 2012c, Vida et al., 2010). In spite of the high conservation value of loess grasslands, only sparse seed bank data is available for their characteristic species. To preserve and restore loess grasslands it is necessary to understand how soil seed banks can contribute to the maintenance of species diversity. A crucial question is whether target species already missing from aboveground vegetation of degraded stands are still present in the soil seed banks.

\section{Aims of the study}

In the present study, we evaluate the seed bank composition of two types of loess grasslands in relation with aboveground vegetation. Vegetation and seed bank composition of (i) a semi-natural loess grassland (Salvio nemorosae - Festucetum rupicolae) traditionally managed by mowing and (ii) a degraded, abandoned loess pasture (Cynodonti - Poëtum angustifoliae) were studied. We asked the following study questions: (i) How dense are the seed banks of loess grasslands? (ii) Which species of the vegetation possess persistent seed banks? (iii) Is the regeneration from seed banks feasible after degradation of loess grasslands?

\section{Material and methods}

\section{Study sites}

The studied grasslands are in the Hortobágy National Park (East-Hungary), near the village Hortobágy (Nyírölapos, degraded loess pasture, N 47³4'47”, E 21 ${ }^{\circ} 15^{\prime} 30^{\prime \prime}$ ) and the town Balmazújváros (Magdolna Puszta, semi-natural loess grassland, N 47³5'01' E $\left.21^{\circ} 17^{\prime} 54^{\prime \prime}\right)$. The vegetation in the region is characterised by alkali grasslands, 
scattered alkali marshes at the lowest and loess grassland patches at the highest elevations (Török et al., 2010, Kelemen et al., 2013). The region is characterized by a moderately continental climate. The mean annual temperature is $9.5 \mathrm{C}$, while the mean annual precipitation is $550 \mathrm{~mm}$ with high among-year variations. The yearly maximum precipitation is typical in June (mean $80 \mathrm{~mm}$ ) with high year-to-year fluctuations (Molnár, 2004).

Nyírölapos site was formerly an overgrazed species-poor loess pasture (Cynodonti Poëtum angustifoliae) till the 1980's. We studied vegetation and seed banks of enclosures established in the 1980's, where no management have been applied.. Abandoned, degraded loess pastures (Cynodonti - Poëtum angustifoliae) are characterised by a high cover of grazing-tolerant grasses, sedges (Cynodon dactylon, Poa angustifolia, Festuca pseudovina, F. rupicola and Carex stenophylla) and forbs (Convolvulus arvensis, Galium verum and Euphorbia cyparissias). At heavily grazed sites, thistles dominate (Eryngium campestre and Ononis spinosa).

In the study region, only small stands of less degraded semi-natural loess grasslands (Salvio nemorosae - Festucetum rupicolae) have remained. The semi-natural grassland in Magdolna Puszta is one of these remnants. The site is traditionally managed by mowing. The characteristic grasses for species-rich loess grasslands are Festuca rupicola, Bromus inermis, Koeleria cristata, Stipa capillata, Alopecurus pratensis and Poa angustifolia. They are rich in perennial forb species, including several characteristic loess-specialist species (Filipendula vulgaris, Fragaria viridis, Pimpinella saxifraga, Salvia nemorosa, Thymus glabrescens, Trifolium striatum and Veronica prostrata).

\section{Vegetation and seed bank sampling}

In each grassland stand, twelve $1-\mathrm{m} \times 1-\mathrm{m}$ plots were marked randomly, and the percentage cover of vascular plants was recorded in June 2009. In the forthcoming spring (2010) three soil cores (4-cm in diameter and 10-cm in depth, $126 \mathrm{~cm}^{3}$ per core,) were drilled from each plot for seed bank analyses (in total 36 soil cores per grassland). Two vertical segments $(0-5-\mathrm{cm}, 5-10-\mathrm{cm})$ were separated; then identical segments from the same plot were pooled. Samples were concentrated by sieving using the method of ter Heerdt et al. (1996). After bulk reduction, samples were spread in 3-4 mm thick layer on surface of trays filled with steam-sterilised potting soil. Germinated seedlings were regularly counted, identified and removed from the trays. Unidentified seedlings were transplanted and were grown until identification. Accidental airborne seed contamination was detected using sample-free control trays filled with steam-sterilised potting soil. Trays were placed in a greenhouse under natural light conditions and watered regularly from April to October. Watering was stopped in early July (when no seedlings emerged) to mimic natural drought conditions during summer. Watering was re-started in late August, and was continued until the early days of November.

\section{Data processing and analysis}

Species were grouped into 'graminoids' (i.e. Poaceae, Cyperaceae and Juncaceae) and 'forbs', i.e. dicots and non-graminoid monocots (including Typhaceae). Species were classified into seed bank types (SBT) based on the classification criteria of Csontos (2001) and Thompson et al. (1997). For seed bank types classification, we used vegetation records and vertical distribution data of the seed bank (seed density scores 
for the $0-5$ and 5-10-cm layers). We assigned species to the following seed bank types: $\mathrm{T}$ - transient, SP - short-term persistent, LP - long-term persistent (Thompson et al., 1997). Seeds of transient species remain viable in the soil seed bank for less than one year, while seeds of persistent species can survive longer. Generally, short-term persistent seeds remain viable for 1-5 years, while long-term persistent ones can germinate even after being more than 5 years in the soil (Thompson et al., 1997). We assigned those species to SBT types which were either (i) present with at least 3 germinated seedlings (corresponding with a seed density of $66 \mathrm{seeds} / \mathrm{m}^{2}$ ) or (ii) were detected in $50 \%$ of the plots in the aboveground vegetation (possessing frequency score of at least 6) in at least one grassland stand. Seedlings of Carex praecox and $C$. stenophylla; Juncus bufonius and J. ranarius; Trifolium angulatum and T. retusum and Typha angustifolia and T. latifolia were pooled because of identification difficulties. Greenhouse weeds detected in control trays were excluded from analyses. Means of species richness of grassland stands were compared using t-test (Zar, 1999). Similarity between the species composition of aboveground vegetation and seed banks was calculated by the Jaccard index. Vegetation and seed bank composition was compared using DCA ordination (Legendre and Legendre, 1998). Nomenclature follows Simon (2000) for taxa and Borhidi (2003) for syntaxa.

\section{Results}

\section{Vegetation composition}

We detected altogether 94 species in the vegetation and seed banks of the two study sites. We found altogether 58 species in the vegetation of the study sites: 24 species in the vegetation of degraded loess pasture and 52 species in the traditionally managed loess grassland, while 18 species were present in the vegetation of both study sites.

We detected significantly lower species numbers in the plots of the degraded loess pasture (Nyírölapos - a mean of $10.2 \mathrm{species} / \mathrm{m}^{2}$ ) than in the semi-natural loess grassland (Magdolna Puszta - a mean of 27.0 species $/ \mathrm{m}^{2}$; t-test, $p<0.001$ ). The vegetation of the degraded loess pasture was characterised by the high cover of Festuca rupicola; only two other species possessed cover scores higher than 5\% (Galium verum and Poa angustifolia; see Table 1 and Table 2). Loess-specialist forb species (e.g. Filipendula vulgaris and Salvia nemorosa) were missing or only present with low cover scores in the degraded loess pasture (Table 2). The vegetation of the semi-natural loess grassland was also characterised by a high cover of Festuca rupicola, and there were four species present with cover scores higher than 5\% (Cynodon dactylon, Filipendula vulgaris, Poa angustifolia and Thymus glabrescens). For detailed species composition, see Figure 1. In the DCA ordination, the aboveground vegetation and seed banks of the two loess grassland stands were clearly separated. A higher patchiness of species composition was detected both for the vegetation and seed banks of the degraded loess pasture compared to the semi-natural loess grasslands (Figure 1).

We detected altogether 68 species in the seed banks. In the seed bank of degraded loess pasture 52 species, in the semi-natural loess grassland 44 species were found, respectively. We detected 28 species in the seed banks of both study sites. We were able to classify 56 species into seed bank types (Thompson et al. 1997; Table 1, Table 2). Total density of seed banks in the two grassland types did not differ significantly; a mean seed density of 22,800 seeds $/ \mathrm{m}^{2}$ in the degraded loess pasture, and $20,200 \mathrm{seeds} / \mathrm{m}^{2}$ in the semi-natural loess grassland were detected, respectively. No 
significant differences were found in seed bank species numbers in the two grassland types (means were 17.0 species $/ \mathrm{m}^{2}$ in the degraded loess pasture and $15.4 \mathrm{species} / \mathrm{m}^{2}$ in the semi-natural loess grassland; t-test, $\mathrm{P}=0.299$ ). The Jaccard similarity of aboveground vegetation and seed banks were 0.31 in the degraded loess pasture and 0.35 in the semi-natural loess grasslands, respectively. In the degraded loess pasture $76 \%$, while in the semi-natural loess grassland $46 \%$ percent of species detected in the aboveground vegetation possessed at least short-term persistent seed banks.

Table 1. Percentage cover and seed density of graminoid species in the degraded (Nyirölapos) and semi-natural (Magdolna Puszta) loess grasslands. Notations: VC: mean cover scores in the aboveground vegetation (\%); VF: frequency scores in the aboveground vegetation; SN: seedling number; SF: frequency scores in the seed bank. SBT: seed bank type: $T$-transient, $S P$ - short-term persistent, LP - long-term persistent (Thompson et al. 1997). One germinated seedling corresponds with a seed density of 22 seeds $/ m 2$. Species with a frequency score of more than six, or more than three germinated seedlings detected in one grassland stand were listed.

\begin{tabular}{|c|c|c|c|c|c|c|c|c|c|}
\hline & \multicolumn{4}{|c|}{ Degraded grassland } & \multicolumn{4}{|c|}{ Semi-natural grassland } & \multirow[b]{2}{*}{ SBT } \\
\hline & $\mathrm{VC}$ & VF & SN & SF & $\mathrm{VC}$ & VF & SN & SF & \\
\hline Agropyron intermedium & & & & & 1.1 & 8 & & & $\mathrm{~T}$ \\
\hline Agropyron repens & 0.8 & 9 & & & & & & & $\mathrm{~T}$ \\
\hline Alopecurus pratensis & 0.5 & 6 & 7 & 1 & 0.4 & 2 & 2 & 2 & $\mathrm{~T}$ \\
\hline Bromus mollis & & & & & 0.2 & 9 & & & $\mathrm{~T}$ \\
\hline Carex praecox/stenophylla & & & 113 & 11 & 2.8 & 11 & 16 & 6 & SP/LP \\
\hline Cynodon dactylon & 0.3 & 3 & & & 7 & 12 & 26 & 10 & $\mathrm{~T}$ \\
\hline Echinochloa crus-galli & & & & & & & 5 & 1 & LP \\
\hline Festuca rupicola & 44.6 & 11 & 5 & 3 & 33.9 & 12 & 31 & 8 & SP \\
\hline Juncus bufonius/ranarius & & & 5 & 4 & & & 6 & 4 & LP \\
\hline Juncus compressus & & & 9 & 6 & & & 45 & 8 & LP \\
\hline Koeleria cristata & 0.1 & 1 & & & 0.6 & 7 & 6 & 4 & $\mathrm{~T}$ \\
\hline Poa angustifolia & 7.2 & 11 & 43 & 11 & 6.1 & 11 & 48 & 11 & SP \\
\hline
\end{tabular}

Out of the most frequent species in the vegetation of the degraded loess pasture, only two forbs, Galium verum (4268 seeds $/ \mathrm{m}^{2}$ ) and Achillea collina (2090 seeds $/ \mathrm{m}^{2}$ ) possessed considerable dense seed banks (higher seed density than $1000 \mathrm{seeds} / \mathrm{m}^{2}$; Table 2). Graminoids present in the aboveground vegetation with high cover scores (like Festuca rupicola and Poa angustifolia) possessed only low-density seed banks (Table 1). Several species sporadically found in the aboveground vegetation, possessed dense seed banks in the degraded loess pasture, like some short-lived weeds (Carduus acanthoides, 860 seeds $/ \mathrm{m}^{2}$ and Conyza canadensis, $6764 \mathrm{seeds} / \mathrm{m}^{2}$ ), sedges (Carex praecox and $C$. stenophylla, 2486 seeds $/ \mathrm{m}^{2}$ ) and wind-dispersed hygrophytes (Epilobium tetragonum, 575 seeds $/ \mathrm{m}^{2}$ ). Loess-specialist forbs detected with low cover scores in the vegetation possessed only sparse (Salvia nemorosa, $66 \mathrm{seeds} / \mathrm{m}^{2}$ ) or no seed banks (Filipendula vulgaris).

Among the most frequent graminoids in the vegetation of the semi-natural loess grassland, only Poa angustifolia possessed considerable seed banks (1061 seeds $/ \mathrm{m}^{2}$ ). Other frequent graminoids of the aboveground vegetation possessed lower seed densities (e.g. Festuca rupicola - $685 \mathrm{seeds} / \mathrm{m}^{2}$, Cynodon dactylon - $545 \mathrm{seeds} / \mathrm{m}^{2}$; Table 1). In the seed bank of the semi-natural loess grassland, eight forb species had 
higher seed density than 500 seeds $/ \mathrm{m}^{2}$; these were Euphorbia cyparissias $\left(685 \mathrm{seeds} / \mathrm{m}^{2}\right)$, Hypericum perforatum $\left(6,233 \mathrm{seeds} / \mathrm{m}^{2}\right)$, Myosotis stricta $\left(1,967 \mathrm{seeds} / \mathrm{m}^{2}\right)$, Plantago lanceolata $\left(1,017 \mathrm{seeds} / \mathrm{m}^{2}\right), \quad$ Potentilla arenaria $\left(1,304\right.$ seeds $\left./ \mathrm{m}^{2}\right)$, P. argentea $\left(1,326 \mathrm{seeds} / \mathrm{m}^{2}\right)$, Stellaria graminea $\left(862 \mathrm{seeds} / \mathrm{m}^{2}\right)$ and

Table 2. Percentage cover and seed density of forb species in the degraded (Nyirölapos) and semi-natural (Magdolna Puszta) loess grasslands. For notations, see Table 1.

\begin{tabular}{|c|c|c|c|c|c|c|c|c|c|}
\hline & \multicolumn{4}{|c|}{ Degraded grassland } & \multicolumn{4}{|c|}{ Semi-natural grassland } & \multirow[b]{2}{*}{ SBT } \\
\hline & $\mathrm{VC}$ & $\begin{array}{l}\text { VF } \\
\end{array}$ & SN & $\overline{S F}$ & $\overline{\mathrm{VC}}$ & $\overline{V F}$ & SN & $\overline{\text { SF }}$ & \\
\hline Achillea collina & 2.6 & 8 & 95 & 11 & 1.7 & 10 & 11 & 6 & SP \\
\hline Arenaria serpyllifolia & & & 7 & 4 & & & & & LP \\
\hline Carduus acanthoides & 0.1 & 4 & 39 & 12 & 0.1 & 1 & 2 & 2 & SP \\
\hline Centaurium minus & & & 4 & 1 & & & & & LP \\
\hline Chenopodium album & & & 5 & 2 & & & 1 & 1 & LP \\
\hline Chenopodium strictum & & & 4 & 3 & & & & & LP \\
\hline Cirsium arvense & & & 5 & 4 & & & & & LP \\
\hline Convolvulus arvensis & 0.2 & 5 & 4 & 2 & 0.1 & 4 & & & $\mathrm{~T} / \mathrm{LP}$ \\
\hline Conyza canadensis & 0.1 & 1 & 307 & 12 & & & & & SP/LP \\
\hline Cruciata pedemontana & & & 8 & 2 & 0.1 & 2 & & & $\mathrm{~T} / \mathrm{LP}$ \\
\hline Cynoglossum officinale & 1.7 & 8 & 5 & 2 & & & & & $\mathrm{~T}$ \\
\hline Daucus carota & & & 2 & 2 & 0.7 & 9 & 3 & 3 & $\mathrm{~T}$ \\
\hline Epilobium tetragonum & 0.1 & 1 & 26 & 9 & & & 6 & 3 & SP \\
\hline Euphorbia cyparissias & 0.2 & 5 & 4 & 3 & 0.3 & 6 & & & $\mathrm{~T} / \mathrm{SP}$ \\
\hline Filipendula vulgaris & 0.4 & 12 & & & 5.5 & 12 & & & $\mathrm{~T}$ \\
\hline Fragaria viridis & 1.1 & 8 & 3 & 1 & 7 & 11 & 1 & 1 & $\mathrm{~T}$ \\
\hline Galium verum & 22.9 & 12 & 194 & 10 & 4.4 & 11 & 3 & 2 & SP \\
\hline Gypsophila muralis & & & 13 & 6 & & & 7 & 5 & LP \\
\hline Hypericum perforatum & & & & & 0.3 & 5 & 283 & 12 & SP \\
\hline Inula britannica & 0.1 & 1 & 8 & 2 & 0.1 & 3 & 1 & 1 & SP \\
\hline Lotus corniculatus & & & & & 0.6 & 7 & 4 & 3 & $\mathrm{~T}$ \\
\hline Medicago falcata & & & & & 1.6 & 7 & & & $\mathrm{~T}$ \\
\hline Medicago lupulina & & & 2 & 2 & & & 5 & 5 & LP \\
\hline Myosotis stricta & & & 20 & 5 & 0.1 & 4 & 89 & 12 & SP/LP \\
\hline Pimpinella saxifraga & & & & & 1.2 & 8 & & & $\mathrm{~T}$ \\
\hline Plantago lanceolata & & & & & 0.5 & 10 & 46 & 10 & SP \\
\hline Polygonum aviculare & 0.1 & 2 & 6 & 4 & 0.1 & 1 & 6 & 4 & SP/LP \\
\hline Potentilla arenaria & 0.1 & 2 & 8 & 4 & 1.3 & 12 & 59 & 12 & $\mathrm{SP}$ \\
\hline Potentilla argentea & 0.2 & 4 & 4 & 3 & & & 60 & 11 & LP \\
\hline Salvia nemorosa & 3.6 & 7 & 3 & 3 & 5.2 & 11 & & & $\mathrm{~T}$ \\
\hline Sonchus asper & & & 6 & 3 & & & & & LP \\
\hline Stellaria graminea & 2.6 & 4 & 1 & 1 & 0.1 & 1 & 39 & 11 & $\mathrm{~T} / \mathrm{SP}$ \\
\hline Thymus glabrescens & & & & & 7 & 12 & 3 & 3 & $\mathrm{~T}$ \\
\hline Trifolium angulatum/retusum & & & 8 & 4 & & & & & LP \\
\hline Trifolium striatum & & & 5 & 3 & 0.6 & 6 & & & $\mathrm{~T} / \mathrm{LP}$ \\
\hline Typha angustifolia/latifolia & & & 4 & 1 & & & 8 & 5 & LP \\
\hline Verbascum phoeniceum & & & 9 & 4 & 1.3 & 12 & 10 & 4 & SP/LP \\
\hline Veronica persica & & & 22 & 6 & & & 55 & 12 & LP \\
\hline Veronica prostrata & & & 1 & 1 & 0.6 & 8 & 1 & 1 & $\mathrm{~T}$ \\
\hline Veronica verna & & & & & 0.3 & 10 & & & $\mathrm{~T}$ \\
\hline Vicia angustifolia & & & & & 0.5 & 6 & & & $\mathrm{~T}$ \\
\hline Vicia lathyroides & & & & & 0.4 & 4 & 13 & 8 & SP \\
\hline
\end{tabular}


Veronica persica $\left(1,216 \mathrm{seeds} / \mathrm{m}^{2}\right)$. Several forb species characteristic to loess grasslands like Knautia arvensis, Pimpinella saxifraga, and Salvia nemorosa had no or at most very sparse seed banks (Table 2).

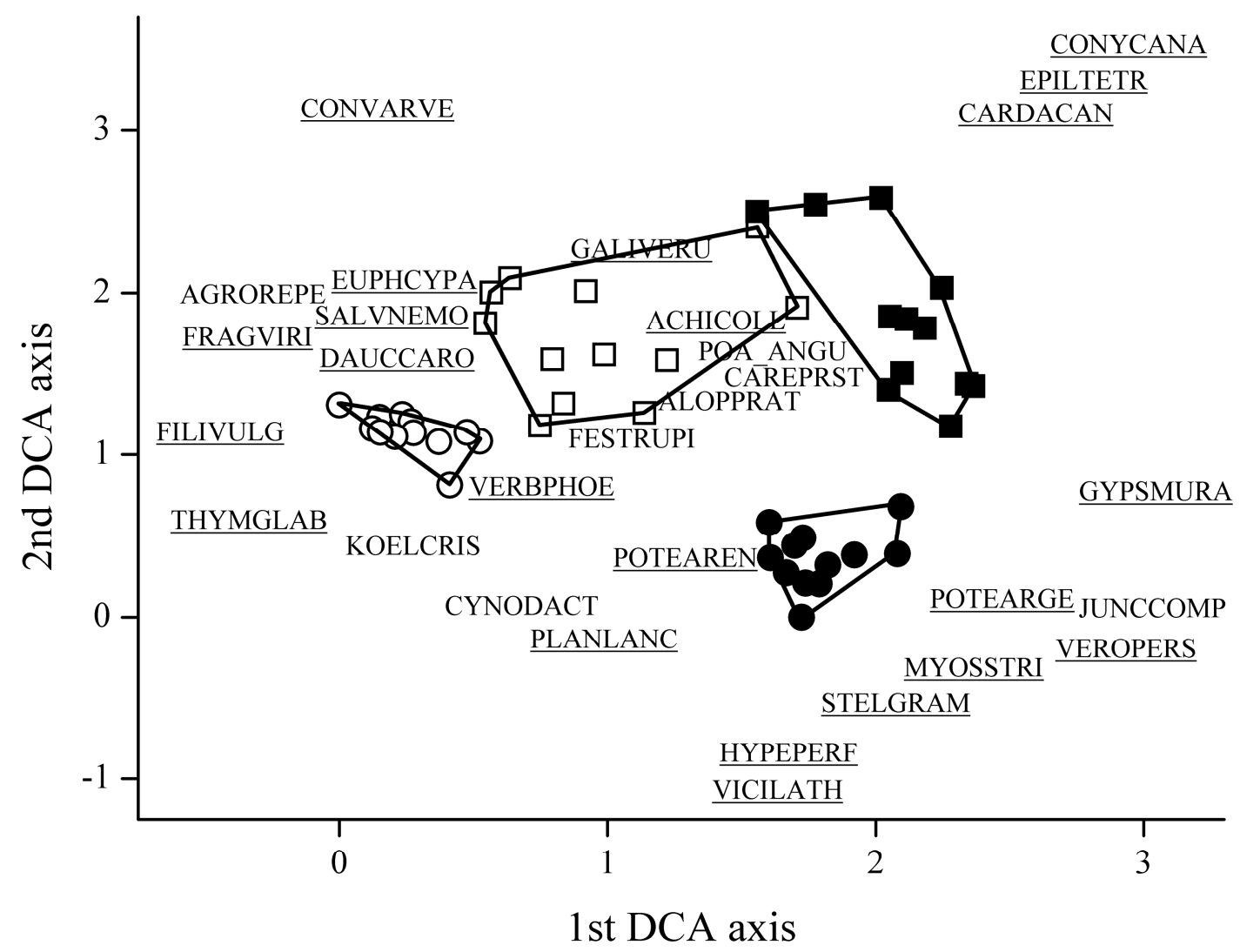

Figure 1. Species composition of vegetation and seed banks of the studied grasslands displayed by a DCA ordination based on presence-absence datasets. Notations: $\square$-degraded loess pasture, vegetation; - degraded loess pasture, seed bank; $\bigcirc$ - semi-natural loess grassland, vegetation; - semi-natural loess grassland, seed bank. The most frequent 30 species are shown, using four letters of their genus and four letters of their species names. Forbs were marked with underlines. Seed bank composition

\section{Discussion}

\section{Seed banks of loess grassland species}

No significant differences were found between the mean seed bank densities of the two types of loess grasslands. Seed bank densities were higher than in other species-rich dry grassland types, like dry calcareous grasslands (200-900 seeds $/ \mathrm{m}^{2}$; Bossuyt et al., 2006 Kalamees and Zobel, 1998) or chalk grasslands (6000-7000 seeds $/ \mathrm{m}^{2}$; Poschlod and Jackel, 1993).

We found that most characteristic species of loess grasslands possessed at most sparse seed banks. For most of the characteristic graminoids in the aboveground vegetation, persistent seed banks were not detected in the two types of loess grasslands. Former seed bank studies in grasslands found that in case of perennial grasses, seed bank formation is often subordinated to clonal reproduction (Bossuyt and Honnay, 2008). In our study, the only perennial grass species with considerable seed densities 
was Poa angustifolia. This generalist grass species was found in high desities in several grassland types (e.g. sandy grasslands, Török et al., 2009), or restored secondary grasslands (Török et al., 2012a).

We found that forb species typical in the aboveground vegetation of the semi-natural loess grassland (e.g. Fragaria viridis, Salvia nemorosa and Thymus glabrescens) possessed no or only sparse seed banks in both loess grassland types. Forb species with considerable seed banks were mainly disturbance-tolerant species (Euphorbia cyparissias, Galium verum, Hypericum perforatum and Potentilla argentea).

\section{Similarity of vegetation and seed banks}

In former studies, low to medium similarity was found between vegetation and seed banks in temperate grasslands (Bossuyt \& Honnay, 2008; Hopfensperger, 2007). This result was also supported by our study: mean Jaccard similarity scores were raging between 0.31 and 0.35 in the studied grassland types. There are several explanations for this phenomenon: (i) Perennial grasses of the aboveground vegetation often lack persistent seed banks (Bakker et al., 1996, Bekker et al., 1997). (ii) Seed banks are mainly characterised by weedy and disturbance-tolerant species missing or underrepresented in the aboveground vegetation in most semi-natural grasslands (Valkó et al., 2011). (iii) For rare species with aggregated seed banks, the probability of detection is low (Thompson et al., 1997). (iv) There is also a high chance for nondetection of short-lived species with high fluctuations in aboveground cover (Török et al., 2009).

\section{Implications for restoration}

Loess grasslands are among the most fragile and vulnerable grasslands harbouring high species diversity (Somodi et al., 2008). In a recent study, Kelemen et al. (2013) found that loess grasslands are especially threatned by degradation, because even a slight change in total biomass production can result in a decrease of species richness in these grasslands. Abandonment or inappropriate management by overgrazing alter biomass conditions in loess grasslands, leading to fewer and less suitable microsites for the germination and establishment of target species (Deák et al., 2010; Miglécz et al., 2013). Our results suggest that the local seed banks have only a minor contribution to the maintenance of diversity in both degraded and semi-natural loess grasslands. Irrespective of the state of degradation, only a small number of species characteristic to loess grasslands built up detectable seed banks. Therefore, loess-specialist species can become locally extinct if they disappear from the aboveground vegetation. Restoration of former species richness is therefore not possible from local seed banks in loess grasslands. Our results underline the importance of the traditional management for the species-rich loess grasslands.

Acknowledgements. I am thankful for B. Tóthmérész, P. Török, O. Valkó, T. Miglécz, A. Kelemen, B. Deák, T. Ölvedi, B. Lukács and Sz. Radócz for their help in fieldwork, seedling emergence and for their useful comments on the manuscript. The help of the staff of UD Botanical Garden in the seed bank study is thankfully acknowledged. The research was partly supported by TÁMOP-4.2.2.C-11/1/KONV-20120010, TÁMOP 4.2.1./B-09/1/KONV-2010-0007 and TÁMOP-4.2.2_B-10_1-2010-0024 projects and OTKA PD 100192. The TÁMOP projects are implemented through the New Hungary Development Plan, co-financed by the European Social Fund and the European Regional Development Fund. 


\section{REFERENCES}

[1] Bekker, R. M., Verweij, G. L., Smith, R. E. N., Reine, R., Bakker, J. P.,Schneider, S. (1997): Soil seed banks in European grassland: Does land use affect regeneration perspectives? - Journal of Applied Ecology 34: 1293-1310.

[2] Borhidi, A. (2003): Magyarország Növénytársulásai (Plant associations of Hungary). Akadémiai Kiadó, Budapest, Hungary.

[3] Bossuyt, B., Butaye, J., Honnay, O. (2006): Seed bank composition of open and overgrown calcareous grassland soils - a case study from Southern Belgium. - Journal of Environmental Management 79: 364-371.

[4] Bossuyt, B., Honnay, O. (2008): Can the seed bank be used for ecological restoration? An overview of seed bank characteristics in European communities. - Journal of Vegetation Science 19: 875-884.

[5] Csiszár, Á. (2004): Adatok a magyar flóra fajainak magbank típus szerinti minősítéséhez. - Tájökológiai Lapok 2: 219-229.

[6] Csontos, P., Tamás, J., Kalapos, T. (1996a): Soil seed banks and vegetation recovery on dolomite hills in Hungary. - Acta Botanica Hungarica 40: 35-43.

[7] Csontos, P., Horánszky, A., Kalapos, T., Lőkös, L. (1996b): Seed bank of Pinus nigra plantations in dolomite rock grassland habitats, and its implications for restoring grassland vegetation. - Annales Historico-Naturales Musei Nationalis Hungarici 88: 6977.

[8] Csontos, P. (2001): A természetes magbank kutatásának módszerei. (Methods of seed bank research; in Hungarian) Scientia Kiadó, Budapest, Hungary.

[9] Csontos, P. (2011): A természetes magbank, valamint a hazai flóra magökológiai vizsgálatának új eredményei. - Kanitzia 17: 77-110.

[10] Deák, B., Valkó, O., Kelemen, A., Török, P. Miglécz, T., Ölvedi, T., Lengyel, Sz., Tóthmérész, B. (2011): Litter and graminoid biomass accumulation suppresses weedy forbs in grassland restoration. - Plant Biosystems 145: 730-737.

[11] Drobnik, J., Römermann, C., Bernhardt-Römermann, M., Poschlod, P. (2011): Adaptation of plant functional group composition to management changes in calcareous grassland. - Agriculture, Ecosystems \& Environment 145: 29-37.

[12] Halassy, M. (2001): Possible role of the seed bank in the restoration of open sand grassland in old fields. - Community Ecology 2: 101-108.

[13] Házi J., Bartha S., Szentes Sz., Wichmann B., Penksza K. (2011): Seminatural grassland management by mowing of Calamagrostis epigejos in Hungary. - Plant Biosystems 145: 699-707.

[14] Házi, J., Penksza, K., Bartha, S., Hufnagel, L., Tóth, A., Gyuricza, Cs., Szentes, Sz. (2012): Cut mowing and grazing effects with grey cattle on plant species composition in case of Pannon wet grasslands. - Applied Ecology and Enviromental Research 10: 223231.

[15] ter Heerdt, G.N.J., Verweij, G.L.R., Bekker, R.M., Bakker, J.P. (1996): An improved method for seed bank analysis: seedling emergence after removing the soil by sieving. Functional Ecology 10: 144-151.

[16] Hopfensperger, K.N. (2007): A review of similarity between seed bank and standing vegetation across ecosystems. - Oikos 116: 1438-1448.

[17] Kalamees, R., Zobel, M. (1998): Soil seed bank composition in different successional stages of a species rich wooded meadow in Laelatu, western Estonia. - Acta Oecologica 19: $175-180$.

[18] Kelemen, A., Török, P., Valkó, O., Miglécz, T., Tóthmérész, B. (2013): Mechanisms shaping plant biomass and species richness: plant strategies and litter effect in alkali and loess grasslands. - Journal of Vegetation Science doi: http://dx.doi.org/10.1111/jvs.12027. 
[19] Kiss, T., Lévai, P.. Ferencz, Á., Szentes, Sz., Hufnagel, L., Nagy, A., Balogh, Á., Pintér, O., Saláta, D., Házi, J., Tóth, A., Wichmann, B., Penksza, K. (2011): Change of composition and diversity of species and grassland management between different grazing intensity - in Pannonian dry and wet grasslands. - Applidied Ecology and Environmental Research 9(3): 197-230.

[20] Koncz, G., Török, P., Papp, M., Matus, G., Tóthmérész, B. (2011): Penetration of weeds into the herbaceous understorey and soil seed bank of a Turkey oak-sessile oak forest in Hungary. - Community Ecology 12(2): 227-233.

[21] Koncz, G., Papp, M., Török, P., Kotroczó, Zs., Krakomperger, Zs., Matus, G., Tóthmérész, B. (2010): The role of seed bank in the dynamics of understory in a turkeysessile oak forest in Hungary. - Acta Biologica Hungarica 61(Suppl.): 109-119.

[22] Kovács-Hostyánszky, A., Körösi, A., Orci, K.M., Batáry, P., Báldi, A. (2011): Set-aside promotes insect and plant diversity in a Central European country. - Agriculture, Ecosystems \& Environment 141: 296-301.

[23] Kovács-Hostyánszki, A., Elek, E., Balázs, K., Centeri, Cs., Falusi, E., Jeanneret, P., Penksza, K., Podmaniczky, L., Szalkovszki, O., Báldi A. (2013): Reply to reviewers' comments on MS „Earthworms, spiders and bees as indicators of habitat and management in a low-input farming region - a whole farm approach" Ecological Indicators 33: 111120.

[24] Legendre, P., Legendre, L. (1998): Numerical Ecology. Elsevier, Amsterdam.

[25] Malatinszky, Á., Ádám, Sz., Saláta-Falusi, E., Saláta, D., Penksza, K. (2013): Planning management adapted to climate change effects in terrestrial wetlands and grasslands. International. - Journal of Global Warming 5: 311-325.

[26] Matus, G., Tóthmérész, B., Papp, M. (2003): Restoration prospects of abandoned speciesrich sandy grassland in Hungary. - Applied Vegetation Science 6: 169-178.

[27] Matus, G., Papp, M., Tóthmérész, B. (2005): Impact of management on vegetation dynamics and seed bank formation of inland dune grassland in Hungary. - Flora 200: 296-306.

[28] Miglécz, T., Tóthmérész, B., Valkó, O., Kelemen, A., Török, P. (2013): Effect of litter on seedling establishment: an indoor experiment with short-lived Brassicaceae species. Plant Ecology 214: 189-193.

[29] Molnár, Zs., Botta-Dukát, Z. (1998): Improved space-for-time substitution for hypothesis generation: secondary grasslands with documented site history in SE-Hungary. Phytocoenologia 28: 1-29.

[30] Molnár, A. (2004): A Hortobágy éghajlati jellemzői. In: Ecsedi, Z. (ed.): A Hortobágy madárvilága. Hortobágy Természetvédelmi Egyesület, Winter Fair, Balmazújváros, Debrecen, pp. 39-43.

[31] Penksza, K., Szentes, S., Loksa, G., Dannhauser, C., Házi, J., (2010): A legeltetés hatása a gyepekre és természetvédelmi vonatkozásai a Tapolcai- és a Káli-medencében. Természetvédelmi Közlemények 16: 25-49.

[32] Penksza K., Házi J., Tóth A., Wichmann B., Pajor F., Gyuricza Cs., Póti P., Szentes Sz. (2013): Eltérő hasznosítású szürkemarha legelő szezonális táplálóanyag tartalom alakulás, fajdiverzitás változása és ennek hatása a biomassza mennyiségére és összetételére nedves pannon gyepekben. - Növénytermelés 62(1): 73-94.

[33] Poschlod, P., Jackel, A-K. (1993): The dynamics of generative diaspore bank of calcareous grassland plants. - Flora 188: 49-71.

[34] Simmering, D., Waldhart, R., Otte, A. (2006): Quantifying determinants contributing to plant species richness in mosaic landscapes: a single and multi-patch perspective. Landscape Ecology 21: 1233-1251.

[35] Simon, T. (2000): A magyarországi edényes flóra határozója (Vascular Flora of Hungary). Nemzeti Tankönyvkiadó, Budapest, Hungary (In Hungarian). 
[36] Somodi, I., Virágh, K., Podani, J. (2008): The effect of the expansion of the clonal grass Calamagrostis epigejos on the species turnover of a semi-arid grassland. - Applied Vegetation Science 11: 187-192.

[37] Szentes Sz., Dannhauser C., Coetzee R., Penksza K, (2011a): Biomass productivity, nutrition content and botanical investigation of Hungarian Grey cattle pasture in Tapolca basin. - AWETH 7(2): 180-198.

[38] Szentes Sz., Dannhauser C., Coetzee R., Penksza K, (2011b): Biomass productivity, nutrition content and botanical investigation of Hungarian Grey cattle pasture in Tapolca basin. - AWETH 7(2): 180-198.

[39] Thompson, K., Bakker, J. P., Bekker, R. M. (1997): Soil seed banks of North West Europe: Methodology, density and longevity. Cambridge University Press, Cambridge.

[40] Török, P., Miglécz, T., Valkó, O., Kelemen, A., Deák, B., Lengyel, Sz., Tóthmérész, B. (2012a): Recovery of native grass biodiversity by sowing on former croplands: Is weed suppression a feasible goal for grassland restoration? - Journal for Nature Conservation 20: $41-48$.

[41] Török, P., Kapocsi, I., Deák, B. (2012b): Conservation and management of alkali grassland biodiversity in Central-Europe. In: Zhang, W. J. (ed.): Grasslands: Types, Biodiversity and Impacts. New York, Nova Science Publishers Inc., pp. 109-118.

[42] Török, P., Kelemen, A., Valkó, O., Deák, B., Lukács, B., Tóthmérész, B. (2011c): Lucerne-dominated fields recover native grass diversity without intensive management actions. - Journal of Applied Ecology 48: 257-264.

[43] Török, P., Deák, B., Vida, E., Valkó, O., Lengyel, Sz., Tóthmérész, B. (2010): Restoring grassland biodiversity: Sowing lowdiversity seed mixtures can lead to rapid favourable changes. - Biological Conservation 148: 806-812.

[44] Török, P., Matus, G., Papp, M., Tóthmérész, B. (2009): Seed bank and vegetation development of sandy grasslands after goose breeding. - Folia Geobotanica 44: 31-46.

[45] Valkó, O., Tóthmérész, B., Kelemen, A., Simon, E., Miglécz, T:, Lukács, B., Török, P. (2013): Environmental factors driving vegetation and seed bank diversity in alkali grasslands. - Agriculture, Ecosystems \& Environment. doi: http://dx.doi.org/10.1016/j.agee.2013.06.012

[46] Valkó, O., Török, P., Matus, G., Tóthmérész, B. (2012): Is regular mowing the most appropriate and cost-effective management maintaining diversity and biomass of target forbs in mountain hay meadows? - lora 207 (4): 303-309.

[47] Valkó, O., Török, P., Tóthmérész, B., Matus, G. (2011): Restoration potential in seed banks of acidic fen and dry-mesophilous meadows: Can restoration be based on local seed banks? - Restoration Ecology 19: 9-15.

[48] Vida, E., Valkó, O., Kelemen, A., Török, P., Miglécz, T., Lengyel, Sz., Tóthmérész, B. (2010): Early vegetation development after grassland restoration by sowing low-diversity seed mixtures in former sunflower and cereal fields. - Acta Biologica Hungarica 61(Suppl.): 246-255.

[49] Virágh, K., Gerencsér, L. (1988): Seed bank in the soil and its role during secondary successions induced by some herbicides in a perennial grassland community. - Acta Botanica Hungarica 34: 77-121.

[50] Zar, J. H. (1999): Biostatistical Analysis. Prentice Hall International, London.

[51] Zimmermann Z., Szabó G., Bartha S., Szentes Sz., Penksza K. (2011): Juhlegeltetés hatásainak természetvédelmi célú vizsgálata legelt és müvelésből kivont gyepek növényzetére. - AWETH 7(3): 234-262. 